\title{
Valg av metode for en landsrepresentativ undersøkelse av kostholdet blant sped- og småbarn i Norge - Spedkost og Småbarnskost
}

\author{
Britt Lande ${ }^{1}$, Lene Frost Andersen ${ }^{2}$, Anne Bærug $^{3}$, Kerstin Trygg $^{2}$, \\ Kari Lund-Larsen ${ }^{4}$ og Gunn-Elin Aa. Bjørneboe ${ }^{1,2}$ \\ ${ }^{1}$ Statens råd for ernoering og fysisk aktivitet \\ ${ }^{2}$ Institutt for ernceringsforskning, Universitetet i Oslo \\ ${ }^{3}$ Nasjonalt ammesenter, Rikshospitalet \\ ${ }^{4}$ Statens noeringsmiddeltilsyn \\ Korrespondanse: Britt Lande, Statens råd for ernæring og fysisk aktivitet, Postboks 8139 dep, 0033 Oslo \\ Telefon: 22249078 telefax: 22249091 e-post: britt.lande@sef.no
}

\begin{abstract}
SAMMENDRAG
I 1998-99 er den første landsrepresentative kostholdsundersøkelsen blant spedbarn og småbarn gjennomført i Norge for å beskrive kostholdet blant barn opp til 2 års alder og relatere kostvanene til de kostanbefalingene som gis. Inntaket av både næringsstoffer og fremmedstoffer skal beregnes. Undersøkelsen inngår i Statens råd for ernæring og fysisk aktivitet (SEF) sitt system for kartlegging av kostholdet i den norske befolkningen, og er et samarbeid mellom SEF, Statens næringsmiddeltilsyn, Institutt for ernæringsforskning ved Universitetet i Oslo og Statistisk sentralbyrå. Hovedmålet er å øke kunnskapen om kostholdet til spedbarn og småbarn i Norge, for å få et bedre grunnlag for å fremme et godt kosthold og forebygge kostholdsrelaterte helseproblemer i denne aldersgruppen. Semikvantitative matvarefrekvensskjema ble vurdert å være den beste metoden å benytte. Det ble utviklet 3 forskjellige selvadministrerte matvarefrekvensskjema (optisk lesbare) for å kartlegge kostholdet blant 6,12 og 24 måneder gamle barn. Bilder av matporsjoner ble inkludert som hjelp til å bestemme mengder. Frekvensskjemaene ble sendt pr. post til mødrene av et landsrepresentativt utvalg av 30006 måneder gamle barn. De samme barna ble fulgt opp ved 12 måneders alder ved at barnas mødre da mottok et nytt frekvensskjema (Spedkost). Videre ble et frekvensskjema sendt mødrene til et landsrepresentativt utvalg av 300024 måneder gamle barn (Småbarnskost). Data for barnas vekt og lengde ble samlet inn i samarbeid med landets helsestasjoner. Det er gjennomført en pilotundersøkelse for å prøve ut frekvensskjemaene og undersøkelsesopplegg. Videre blir frekvensskjemaene validert mot veid registrering over 7 dager. Datainnsamlingen ble avsluttet i juli 1999, og rapporter fra undersøkelsen er ventet i år 2000. Hensikten med artikkelen er å beskrive metoden og begrunne valg av metode for Spedkost og Småbarnskost.
\end{abstract}

Lande B, Frost Andersen L, Bærug A, Trygg K, Lund-Larsen K, Bjørneboe G-EAa. Development of a method for use in a national representative dietary survey among Norwegian infants and children Spedkost/Småbarnskost. Nor J Epidemiol 2000; 10 (1): 43-50.

\section{ENGLISH SUMMARY}

In 1998-99 the first Norwegian national dietary survey among infants and children was conducted in order to describe the dietary habits among children up to the age of 2 years, and to relate these habits to the dietary recommendations. Intakes of both nutrients and non-nutrients will be estimated. The survey is part of the national food surveillance system in Norway, and is a collaboration between the National Council on Nutrition and Physical Activity, the Norwegian Food Control Authorities, the Institute for Nutrition Research (University of Oslo) and Statistics Norway. The main objective is to increase the knowledge about dietary habits among Norwegian infants and young children in order to promote a healthy diet and prevent diet-related health problems in this age group. A self-administered semi-quantitative food frequency questionnaire was considered the best method. Three questionnaires were developed to assess dietary intake among 6,12 and 24 months old children. Pictures were included to help with decisions of portion sizes. The semi-quantitative food frequency questionnaire (FFQ) was distributed to the mothers of a national representative sample of 30006 months old infants. This cohort of infants was followed up at 12 months of age, when their mothers received a new FFQ (Spedkost). Furthermore, a FFQ was distributed to the mothers of a national representative sample of 300024 months old children (Småbarnskost). Data on weight and length were collected in cooperation with the child health centres. A pilot study was conducted in cooperation with the child health centres to test the questionnaires and study design. Furthermore, the questionnaires are validated against 7 days weighed record of food intake. The data collection was closed in July 1999, and reports of the survey are expected in 2000. The purpose of this article is to describe the method and discuss the choice of method for the national dietary survey among infants and young children - Spedkost/Småbarnskost. 


\section{INNLEDNING}

Sped- og småbarnstiden er preget av rask vekst og utvikling, og et godt kosthold i denne perioden er av grunnleggende betydning for barnets helsetilstand. Vekst- og ernæringsforhold $i$ tidlige barneår kan dessuten ha betydning for sykelighet og dødelighet senere $\mathrm{i}$ livet $(1,2)$.

I 1980- og 1990-årene er det gjennomført flere undersøkelser av sped- og småbarns kosthold i Norge (3-9), de fleste i mindre utvalg. I 1998-99 ble den første landsdekkende kostholdsundersøkelsen (Spedkost og Småbarnskost) gjennomført blant 6, 12 og 24 måneder gamle barn. Spedkost og Småbarnskost er et samarbeid mellom Statens råd for ernæring og fysisk aktivitet (tidligere Statens ernæringsråd), Statens næringsmiddeltilsyn (SNT), Institutt for ernæringsforskning ved Universitetet i Oslo og Statistisk sentralbyrå (SSB). Undersøkelsen inngår i og kompletterer Statens råd for ernæring og fysisk aktivitet (SEF) sitt system for kartlegging av kostholdet i den norske befolkningen. Systemet inkluderer allerede opplegg for kartlegging av hhv. unges og voksnes kosthold; Ungkost 1993 (10,11), Norkost 1993-94 (12) og Norkost 1997 (13). Det legges opp til at undersøkelsene gjentas med ca. 5 års mellomrom. Dette gir mulighet til å følge kostholdsutvikling og -trender i Norge.

Hovedmålet med Spedkost og Småbarnskost er å øke kunnskapen om kostholdet til spedbarn og småbarn i Norge, for å få et bedre grunnlag for å gi råd om kosthold og forebygge kostholdsrelaterte helseproblemer i denne aldersgruppen. Kostholdsundersøkelsene skal fremskaffe data som gir grunnlag for:

- å beskrive kostvaner

- å vurdere den ernæringsmessige kvaliteten

- å vurdere om kostholdsvanene er i tråd med de anbefalinger som blir gitt

- å vurdere faktorer som forklarer forskjeller i kostholdet

- å skaffe oversikt over innholdet av fremmedstoffer i kostholdet

- å bidra til at det blir etablert et system for å kunne følge kostholdsutviklingen over tid.

Hensikten med denne artikkelen er å beskrive metoden og begrunne valg av metode for Spedkost og Småbarnskost.

\section{DATA DET ER BEHOV FOR INNEN SPED- OG SMÅBARNSERN/ERING}

Innen sped- og småbarnsernæring er det et stort behov for økt kunnskap her i landet. Vi mangler data som kan gi grunnlag for å beskrive kosthold og kostholdsvaner i denne aldersgruppen på landsbasis. Hvilke data det er behov for å samle inn, får stor betydning for valg og utforming av metode. I det følgende beskrives og begrunnes kort hvilke data det var nødvendig å samle inn for å kunne oppfylle undersøkelsens målsettinger.

\subsection{Kostvaner og matvareinntak}

Data om amming er en viktig helseindikator. Det anbefales at spedbarn får morsmelk som eneste næring de første 4-6 levemånedene og sammen med annen mat hele det første leveåret (14). Liestøl, Rosenberg og Walløe (15) kartla ammeutviklingen i Norge gjennom en 120-årsperiode, fra 1860 og fram til 1984, på bakgrunn av ammedata registrert i Oslo, Bergen og Trondheim. Fra 1982 til 1994 ble amming registrert i forsøksprosjektet SYSBARN (System for barnehelseog vaksinasjonskontroll) i 5 fylker i Sør-Norge (16). Disse undersøkelsene har vist hvordan amming har endret seg over tid. Fra 1994 og til i dag foreligger ikke ammestatistikk for Norge. Undersøkelser fra Norge (17-19) og andre land, som Danmark (20) og Storbritannia (21), viser at ammevarighet varierer, særlig etter mors utdanningsnivå, alder, røyking og sivilstatus. Kunnskap om dette er svært viktig med tanke på valg av strategier for å utjevne ulikheten i amming.

Andre sentrale temaer er bruk av morsmelkerstatninger, introduksjon av fast føde og forebygging av allergi. Det anbefales at spedbarn som ikke får morsmelk, hovedsaklig bør få morsmelkerstatning de første 10-12 månedene. Fast føde bør introduseres gradvis ved 4-6 måneders alder (14). På bakgrunn av tidligere undersøkelser av spedbarns kosthold her i landet, kan det se ut til å være en tendens til at fast føde introduseres senere på 1990-tallet enn på 1980-tallet $(3,4,7,22)$. I forhold til allergiutvikling tyder undersøkelser på at morsmelk som eneste næring de første 4-6 levemåneder kan ha en positiv virkning (23).

I årene som kommer kan matvaretilbudet til spedog småbarn komme til å endre seg som følge av økt internasjonalisering av barnematmarkedet. EUs barnematdirektiv skal i henhold til EØS-avtalen innføres i Norge. Norske myndigheter har imidlertid i 1999 bedt EU-kommisjonen om at det blir gjort en ny vurdering av det faglige grunnlaget for direktivet, fordi man er bekymret for at det bl.a. kan føre til for høyt inntak av enkelte næringsstoffer (24).

På bakgrunn av dette er det behov for ytterligere kunnskap om:

- matvareinntak og forskjeller i matvareinntak mellom grupper

- varighet av fullamming (morsmelk som eneste næring) og delvis amming (morsmelk sammen med annen mat/drikke)

- forskjeller i amming mellom grupper

- introduksjonstidspunkt og bruk av morsmelkerstatninger og kumelk

- praksis når det gjelder introduksjon av fast føde, hvilke matvaretyper som introduseres først og oppfølging av forebyggende råd $i$ forhold til allergi

- dagens praksis i forhold til bruk og inntak av industriframstilte barnematprodukter.

\subsection{Ernaeringsmessig kvalitet}

Det finnes liten kunnskap om energi- og fettinntak og fettkvalitet i kostholdet til sped- og småbarn i Norge. 
Sett i forhold til dagens helseproblemer er det spesielt viktig å følge utviklingen av kostens fettinnhold, både med hensyn til totalt fettinnhold og -type. Danske forskere (25) vurderer at fettinntaket til barn ikke bør begrenses de første 2-3 leveårene, mens en finsk forskergruppe har funnet at næringsinntak og vekst ikke er signifikant forskjellig etter ulikt fettinntak (26).

Ved våre breddegrader, med begrenset eksponering for sollys, vil de fleste barn ha behov for tilførsel av vitamin D via kost eller tilskudd for å forebygge rakitt. Alle spedbarn anbefales et daglig tilskudd av vitamin D fra 4 ukers alder, fortrinnsvis $\mathrm{i}$ form av $5 \mathrm{ml}$ tran (14).

Undersøkelser har vist at jernmangelanemi forekommer blant sped- og småbarn i Norge (4-7,27). Flere forhold synes å påvirke jernstatus: varighet av perioden med fullamming, inntak av andre melketyper, jernrike matvarer, vitamin $\mathrm{C}$, måltidssammensetning og inntak av sukkerrike matvarer istedenfor mer næringsrik mat. Det pågår nå en undersøkelse i Norge (9) som ytterligere vil belyse jernstatus og forhold som påvirker jernstatus hos barn i alderen 0-2 år.

På bakgrunn av dette er det behov for ytterligere kunnskap om:

- inntak av energi og næringsstoffer generelt

- fettinntak og fettkvalitet

- inntak av vitamin D fra kosten og om bruk av tran og andre vitamin D-tilskudd

- bruken av jernberikede produkter, andre matvarer og av kostmønstre som kan tenkes å påvirke jernstatus i de første leveårene.

\subsection{Anbefalinger for spedbarnsernaring og naeringsstoffanbefalinger}

Kongsvinger-undersøkelsen fra begynnelsen av 1980 tallet viste at helsetjenestens anbefalinger for spedbarnsernæring i stor grad ble fulgt (3). I hvilken grad dette fortsatt gjelder, er det begrenset kunnskap om. Statens ernæringsråd (nå Statens råd for ernæring og fysisk aktivitet) utarbeidet i 1993 nye anbefalinger for spedbarnsernæring (14). SEF gir også anbefalinger for ernæringsmessig sammensetning av kostholdet - næringsstoffanbefalinger - rettet mot hele befolkningen og grupper av befolkningen. De nyeste næringsstoffanbefalingene kom i 1997 (28) og gir anbefalinger for fordeling av energigivende næringsstoffer, inntak av vitaminer, mineraler og referanseverdier for energiinntak i aldersgruppen 0-3 år.

Det er behov for ytterligere kunnskap om:

- i hvilken grad anbefalingene for spedbarnsernæring blir fulgt

- inntak av energi og næringsstoffer vurdert i forhold til næringsstoffanbefalingene.

\subsection{Fremmedstoffer}

Fremmedstoffer omfatter tilsetningsstoffer i mat og kjemisk forurensning, både $\mathrm{i}$ form av plantevernmidler og andre miljøgifter. Barn er spesielt utsatt for uheldige virkninger av fremmedstoffer, fordi de vokser og utvikler seg raskt, og fordi de kan få et stort inntak i forhold til kroppsvekt. Statens næringsmiddeltilsyn gjennomfører undersøkelser av fremmedstoffinnhold i barnematprodukter. Det er hittil funnet lave verdier i produktene som er analysert. Utvikling av nye matvareprodukter og eventuelle endringer i regelverket for bruk av tilsetningsstoffer er forhold som også gjør det viktig å få en oversikt barnas kostvaner.

Det er behov for mer kunnskap om hva barn i Norge spiser for å kunne beregne inntaket av fremmedstoffer og vurdere risiko knyttet til dette.

\subsection{Sammenhengen mellom barns vekst og kostvaner}

Barns vekst er i andre nordiske land undersøkt i forhold til faktorer som amming, fettinntak, energi- og næringsstoffinntak $(25,26)$. En norsk undersøkelse har sett på barns vekst i første leveår i forhold til mors røyking og ammevarighet (17). Ved vurdering av barnas matvare-, energi- og næringsstoffinntak er det viktig å kunne relatere dette til barnas vekt. Barnas vekt og lengde måles på helsestasjonene ved de jevnlige helsekontrollene. Data om barnas vekt og lengde vil dessuten kunne gi grunnlag for å beskrive vekstutvikling første leveår og å vurdere vekstutviklingen i forhold til amming og ulike typer kosthold, for eksempel nivåer av energi- og fettinntak.

\section{PilotundersøKelse}

Mangel på erfaringer med kostholdsundersøkelser i landsdekkende utvalg av sped- og småbarn, gjorde det spesielt nødvendig å gjennomføre en pilotundersøkelse. Formålet med piloten var:

- Å prøve ut hvordan et undersøkelsesopplegg på helsestasjonene fungerer

- Å undersøke om spørreskjemaene er forståelige og om de fanger opp det de skal

- Å teste forskjellige typer spørsmålsstillinger i spørreskjemaene.

Det ble utviklet 3 matvarefrekvensskjemaer (avsnitt 4.3) som skulle testes ut; ett for hvert alderstrinn. 6månedersskjemaet og 2-3-årsskjemaet ga frekvensdata, samt noen mengdedata, mens 12-månedersskjemaet ga både frekvens- og mengdedata og grunnlag for næringsberegning. Det ble i tillegg utviklet et evalueringsskjema som pilotdeltakerne skulle fylle ut.

Deltakerne ble rekruttert via utvalgte helsestasjoner. Piloten skulle inkludere ca. 40 barn i hver av de aktuelle aldersgruppene. Helsestasjoner i 16 bydeler $i$ Oslo ble forespurt, og 9 helsestasjoner (fra 6 bydeler i Oslo) ønsket å delta. Med en forventet svarprosent fra deltakerne på minimum $80 \%$, ble inklusjonsperioden beregnet til 4 uker. Alle barn i aktuell alder (ekskl. innvandrerbarn) som kom til ordinær konsultasjon på helsestasjonene i løpet av en 4 ukers periode (novem- 
ber-desember 1997) ble invitert med, totalt 167 barn. I piloten blant 6- og 12-måneder gamle barn ble informasjonsskriv, matvarefrekvensskjema og evalueringsskjema delt ut til alle som kom til helsestasjonen på hhv. 5- og 10-månederskontroll. Foreldrene tok med skjemaene hjem for utfylling, og tok de med til neste helsestasjonsbesøk - dvs. ved hhv. 6- og 12-månederskontrollen. I piloten blant 2-3 år gamle barn ble informasjonsskriv, frekvensskjema og evalueringsskjema delt ut til alle som kom til helsestasjonen på 2-3årskontroll. Skjemaene ble, om mulig, fylt ut mens foreldre/foresatte og barn var på helsestasjonen. Dersom dette ikke lot seg gjøre, fikk foreldrene med seg skjemaene hjem for utfylling, sammen med en frankert svarkonvolutt. Helsesøster fylte ut data om barnets vekt og lengde i frekvensskjemaene. Helsestasjonene sendte de utfylte frekvens- og evalueringsskjemaene til prosjektledelsen, sammen med en samlet oversikt over antall inviterte og antall deltakere. Alle som deltok fikk en bokgave til barnet, og helsestasjonen fikk økonomisk kompensasjon for ekstraarbeidet med undersøkelsen.

Det var totalt 144 som leverte ferdig utfylt frekvensskjema. Det ga en samlet svarprosent på 86 . Svarprosenten var høyest ved 6 måneder; $93 \%(\mathrm{n}=53)$. Ved 12 måneder deltok $78 \%(\mathrm{n}=43)$ og ved 2-3 år $87 \%(n=48)$. Frekvensskjemaene ble kodet og lest inn manuelt. I databearbeidingen ble det satt opp frekvensfordelinger for alle spørsmålene. Feilavkrysninger ble registrert. Resultater om ammevaner, frekvenser for bruk av mat og drikke og bakgrunnsvariablene ble satt opp. For 12-månedersdataene ble inntak av energi og energigivende næringsstoffer beregnet. Resultatene fra evalueringen viste at en stor andel av deltakerne ved alle alderstrinn vurderte at utfyllingen av skjemaet var "svært enkelt"/"enkelt"/"ganske enkelt". De fleste rapporterte at spørsmålene ikke var sensitive å svare på. Bilder til bestemmelse av porsjoner ble vurdert som nyttig av svært mange. Hovedresultater fra denne evalueringen er gitt $i$ tabell 1 .

Hovedkonklusjonen fra piloten var at svarprosenten ble svært høy. Samarbeid og gjennomføring i helsestasjonen fungerte meget godt, men gjennomføringen krever informasjon, kontakt og koordinering mellom helsestasjoner og prosjektledelse og medfører ekstraoppgaver for helsestasjonene. Noe over halvparten av de forespurte helsestasjoner ønsket å delta. Frekvensfordelingen mht. kostholds-, vekst- og bakgrunnsdata viste sannsynlige verdier. Næringsberegning ved 12 måneder viste et inntak av energi og energigivende stoffer på linje med resultater fra undersøkelser i samme aldersgruppe i Norge. En stor andel av deltakerne vurderte at spørsmålene var forståelige og frekvensskjemaene greie å fylle ut. Det var noen spørsmål som burde endres for å gjøre det mer forståelig. De aller fleste vurderte at ingen av spørsmålene var for sensitive å svare på. Dessuten fant svært mange at bruk av bilder var nyttige ved bestemmelse av matmengder.

\section{VALG AV UTVALG, DESIGN OG METODE}

\subsection{Utvalg}

I Spedkost er barn i alderen 6 og 12 måneder inkludert, mens 24 måneder gamle barn er inkludert i Småbarnskost. Seks måneders alder er valgt for å kartlegge forhold rundt introduksjon av fast føde og amming. Ved å velge 12 måneders alder får vi ammedata for hele første leveår, og kostholdsutviklingen $i$ første leveår kan beskrives. Kartleggingen av kostholdet ved 6- og 12måneders alder kan videre samkjøres med innhenting av vekt- og lengdedata ved hhv. 6- og 12-månederskontrollen på helsestasjonen. Innen aldersgruppen 1-3 år falt valget på 2 års alder. Barnas kosthold forandres mot slutten av første og $\mathrm{i}$ andre leveår, når barna går over fra en spesiell spedbarnskost til familiens kosthold (3-5). Ved å velge 2 år får vi også ammedata for andre leveår.

Statistisk sentralbyrå sto for utvalgstrekking. Det ble vurdert at et bruttoutvalg pr. alderstrinn på $3000 \mathrm{er}$ nødvendig for å oppnå landsrepresentative utvalg.

Utvalget på 30006 måneder gamle barn inkluderte alle spedbarn som ble født i Norge i en 3-ukers periode fra 27.04.98 til 17.05 .98 av norske/andre skandina-

Tabell 1. Deltakernes evaluering av matvarefrekvensskjemaene benyttet i pilotundersøkelsen for Spedkost/Småbarnskost ved 6 måneders, 12 måneders og 2-3 års alder.

\begin{tabular}{|c|c|c|c|}
\hline Vurdering av frekvensskjemaet & $6 \mathrm{mnd}(\mathrm{n}=53)$ & 12 mnd $(n=43)$ & $2-3$ år $(n=47)$ \\
\hline Lengden på skjemaet - Passe/ganske passe & $84 \%$ & $72 \%$ & $81 \%$ \\
\hline Utfylling av skjemaet - Svært enkelt/enkelt/ganske enkelt & $83 \%$ & $84 \%$ & $63 \%$ \\
\hline Enkelte vanskelige spørsmål & $34 \%$ & $21 \%$ & $23 \%$ \\
\hline Spørsmål om kosthold tilbake i tid - Svært enkelt/enkelt/ganske enkelt & $88 \%$ & $76 \%$ & $73 \%$ \\
\hline Spørsmål om frekvens - Svært enkelt/enkelt/ganske enkelt & $92 \%$ & $80 \%$ & $65 \%$ \\
\hline Spørsmål om porsjoner - Svært enkelt/enkelt/ganske enkelt & $92 \%$ & $75 \%$ & $69 \%$ \\
\hline Bildeark (6 mnd)/bildehefte (12 mnd) - God hjelp/noe hjelp & $72 \%$ & $90 \%$ & Ikke benyttet \\
\hline Spørsmål om hva barnet vanligvis spiser - Svært enkelt/enkelt/ganske enkelt & $82 \%$ & $73 \%$ & $68 \%$ \\
\hline Ubehagelig å svare på noen av spørsmålene & $0 \%$ & $0 \%$ & $2 \%$ \\
\hline Villig til å delta i endelig undersøkelse & $79 \%$ & $79 \%$ & $83 \%$ \\
\hline
\end{tabular}


viske mødre. De samme barna ble fulgt opp ved 12måneders alder. Utvalget ble designet ved at startdatoen ble satt til 27.04.98, så ble 3000 barn trukket fortløpende, slik at det siste barnet hadde fødselsdag 17.05.98. Kriterier for å komme med i utvalget var at barna skulle være født av mødre som er født i Norge, Sverige eller Danmark, og at kun ett barn (det eldste) fra tvilling- eller trillingkull skulle være med.

Det antas at kostholdet i denne gruppen ikke skiller seg fra kostholdet til barn født på andre tider av året. Likheten mellom "utvalget" (barn født i fødselsperioden som undersøkes) og "populasjonen" (barn født i 1998) i fordelingen av kjennemerker som barnets kjønn, mors alder og landsdel er funnet ivaretatt $(29,30)$. Tilsvarende gjaldt også for utvalget $\mathrm{i}$ undersøkelsen blant 2-åringer (31). Utvalget på 3000 24 måneder gamle barn inkluderte alle barn født i Norge i perioden 8.03.97-27.03.97 av norske/andre skandinaviske mødre.

Innvandrerbarn inngår ikke i undersøkelsen. Det bør gjennomføres egne undersøkelser av innvandrerbarns kosthold, hvor metoden som velges må kunne fange opp til dels svært ulike matvaner i ulike innvandrergrupper.

\subsection{Design}

Ammemønsteret og kostholdsutviklingen i første leveår er av særlig interesse. Derfor er det valgt å gjennomføre en longitudinell studie, hvor man følger samme utvalg gjennom første leveår. Undersøkelsen i andre leveår er en tverrsnittsstudie.

To ulike tilnærminger til rekruttering av deltakere ble vurdert; invitasjon til deltakelse via helsestasjonene (som i piloten) hvor utvalgsenheten er landets helsestasjoner eller invitasjon per post hvor utvalget trekkes fra et personregister. En klar fordel ved rekruttering via helsestasjonene er en forventet høy svarprosent. Erfaringer fra pilotundersøkelsen viste at samarbeidet med helsestasjonene fungerte meget godt og ga en høy svarprosent, men i en landsdekkende undersøkelse vil det kreve atskillig mer å rekruttere og instruere et utvidet antall helsestasjoner, samt å koordinere datainnsamlingen etter nøye fastsatte rutiner. Andre ulemper er liten kjennskap til utvalget og dermed vanskelige purrerutiner, og usikkerhet om i hvilken grad de utvalgte helsestasjonene har anledning til å delta og ekstraarbeidet undersøkelsen medfører for helsestasjonene. A trekke utvalget fra et personregister vil derimot gi god kontroll og kjennskap til utvalget, noe som vil lette datainnsamling, inkludert purrerutiner. Denne metoden vil være atskillig enklere å administrere, mindre ressurskrevende og mer anvendelig med tanke på framtidig system for kartlegging av kostholdet. En klar ulempe ved at invitasjonen sendes per post er en lavere svarprosent, og motivasjon og premiering av deltakerne må dermed vektlegges i større grad. På bakgrunn av en totalvurdering av fordeler og ulemper ved de ulike rekrutteringsmetodene, vurdering av praktisk gjennomførbarhet og erfaringer fra pilotundersøkelsen, ble det bestemt at utvalget skulle trekkes fra et personregister og invitasjonen sendes ut per post.

Datainnsamlingen ble gjennomført i oktober-desember 1998 for 6-månedersundersøkelsen, i april-juli 1999 for 12-månedersundersøkelsen og i februar-juli 1999 for 24-månedersundersøkelsen. Barnets mor fikk tilsendt brev og frekvensskjema fra Statistisk sentralbyrå ca. 2 uker før barnet ble hhv. 6, 12 og 24 måneder gamle. Skjemaene ble sendt ut i 2-3 puljer over en tre ukers periode. Barnets mor/far/annen omsorgsperson fylte ut skjemaet hjemme i forkant evt. i etterkant av helsestasjonskontrollen, så tett opptil hhv. 6-, 12- og 24-måneders alder som mulig. Foreldrene tok med skjemaet til helsestasjonskontrollen ved hhv. 6-måneders, 12-måneders og 2-års alder. Helsestasjonspersonalet målte barnets vekt og lengde og påførte disse dataene på skjemaet, sammen med opplysninger om barnets fødselsvekt og -lengde. Foreldrene returnerte ferdig utfylt skjema i frankert svarkonvolutt. Hele utvalget fikk en kombinert påminning/takk ca. 2 uker etter første utsendelse. Det ble gjennomført 1 purrerunde med vedlagt skjema (og bildehefte) 4-8 uker etter første utsendelse (varierte avhengig av svarinngangen). De som ikke hadde fylt ut opplysninger om barnets vekt og lengde i 6- og 12-månedersskjemaet, ble tilskrevet for å få påført disse dataene på eget ark. Det er vanskeligere å få registrert vekt og lengde på alle deltakerne i Småbarnskost. Noen helsestasjoner har 2-årskontrollen tett opp til barnets 2-årsdag, mens andre har kontrollen ved 2 1/2 års alder. Deltakerne og helsestasjonene ble imidlertid bedt om å prøve å få til en vekt/lengdemåling av barna selv om ikke barnet var satt opp til 2-årskontroll i perioden.

Rapporter om utvalg og gjennomføring av datainnsamlingen for undersøkelsene foreligger (29-31).

Det ble følgende svarprosenter (etter purring); $80 \%$ for 6-månedersundersøkelsen, 66 \% for 12-månedersundersøkelsen og $58 \%$ for 24-månedersundersøkelsen.

Alle deltakerne i Spedkost/Småbarnskost som returnerte spørreskjemaet i utfylt stand, var med i trekkingen av 5 gavekort á kr 2000. Dette gjaldt for hver av undersøkelsene.

Alle landets helsestasjoner fikk i forkant av hver av undersøkelsene brev med informasjon om Spedkost/ Småbarnskost, det aktuelle frekvensskjemaet til orientering og en plakat til å henge opp på helsestasjonen som påminning og motivasjon til foreldrene. Helsestasjonene ble bedt om å veie og måle lengden på barna, og føre disse opplysningene inn i skjemaene. De ble også bedt om å delta som støttespillere i arbeidet for å motivere foreldrene til deltakelse.

Statistisk sentralbyrå hadde hovedansvar for utsending og innsamling av spørreskjema, optisk lesing av skjemaene og etablering av rådatafiler.

\subsection{Metode}

Det er knyttet en del spesielle problemer til kartlegging av kostholdet blant sped- og småbarn i tillegg til 
de vanlige metodeproblemene ved kostholdsundersøkelser. For det første preges sped- og småbarnsalderen av hurtige forandringer i kostholdet. For det andre er det ofte nødvendig med opplysninger fra flere personer, for eksempel foreldre, dagmamma og barnehagepersonell, for å få et mest mulig riktig bilde av kostholdet. For det tredje kan det være vanskelig å få kvantitative data pga. at barna søler med maten, særlig etter at barna begynner å spise selv, og dette tapet kan det være vanskelig å gjøre rede for. En fordel i arbeidet med å kartlegge kostholdet til sped- og småbarn, er at de ofte konsumerer et mer begrenset utvalg av mat og drikke, spesielt det første leveåret.

Kostholdsundersøkelser blant sped- og småbarn i Norge er gjennomført ved hjelp av følgende metoder; 24-timers kostintervju, 48-timers kostintervju og 7dagers veid registrering av kostholdet (3-9). Dette er til dels meget arbeids- og ressurskrevende metoder, og mindre egnet til bruk i store utvalg.

Det ble tidlig i prosessen valgt å bruke semikvantitative matvarefrekvensskjemaer i Spedkost/Småbarnskost. Dette ble vurdert som beste metode for å oppfylle målsetningen for undersøkelsen og for å sikre en rask bearbeiding og hurtig rapportering. Dessuten er metoden mindre ressurs- og arbeidskrevende. Denne metoden er også benyttet i de to andre landsdekkende kostholdsundersøkelsene blant hhv. voksne og ungdom; Norkost og Ungkost.

Ved utvikling av frekvensskjemaene som er brukt i Spedkost og Småbarnskost, har vi kunnet dra nytte av erfaringene med frekvensskjemaene benyttet i Norkost og Ungkost. Det er utviklet tre forskjellige spørreskjemaer; ett for hvert alderstrinn, da enkelte av spørsmålene som inngår i frekvensskjemaene varierer mellom de tre alderstrinnene. I matvarefrekvensskjemaene spørres det om hvor ofte og hvor mye som spises av forskjellige matvarer. Det er anvendt faste svarkategorier i størst mulig grad. Frekvensskjemaene skal gi et bilde av det vanlige kostholdet til sped- og småbarn. Ettersom kostholdet kan variere mye fra dag til dag i aldersgruppene som er inkludert i Spedkost og Småbarnkost, blir foreldrene bedt om å tenke på kostholdet de siste 14 dager ved utfylling. Dataene fra frekvensskjemaene skal gi grunnlag for å beskrive det gjennomsnittlige kostinntak til en gruppe og til å rangere individer $\mathrm{i}$ forhold til inntak. I tillegg til frekvensskjemaene er det utviklet bildehefte og bildeark, som skal være en hjelp ved bestemmelse av hvor store mengder barna spiser.

Etter piloten ble de tre matvarefrekvensskjemaene og bildeheftet revidert med bakgrunn i erfaringene fra pilotundersøkelsen. Dessuten ble skjemaene gjort optisk lesbare.

Matvarefrekvensskjemaene som er benyttet i Spedkost/Småbarnskost er på 12-16 sider, og er delt opp i følgende temaområder:

- Vekt og lengde ved fødsel og ved hhv. 6-, 12- og 24-måneders alder

- Bakgrunnsspørsmål om barnet
- Spørsmål om barnets kosthold (inkludert ammespørsmål)

- Spørsmål om tran/vitamin- og mineraltilskudd

- Spørsmål om foreldrenes informasjonskilder, -behov og -ønsker i forhold til amming og sped- og småbarnsbarnsernæring

- Bakgrunnsspørsmål om barnets mor og far.

I 6-månedersskjemaet er det spørsmål om amming, introduksjonstidspunkt for morsmelkerstatninger/annen melk og for ulike matvarer. Det er spørsmål om frekvens av matvarer - dvs. hvor ofte visse matvarer spises og drikkes, samt mengder for morsmelkerstatninger/annen melk og for industrilaget grøt. Det er også spørsmål om kostvaner før barnet ble 6 måneder. I 12- og 24-månedersskjemaet er det spørsmål om både frekvens og mengder av matvarene. Dette gir grunnlag for å beregne inntak av matvarer, energi og næringsstoffer. 12- og 24-månedersskjemaet er derfor mer omfattende å fylle ut enn 6-månedersskjemaet. 12- og 24-månedersskjemet er svært like, men det er noen flere ammespørsmål i 12-månedersskjemaet, og dette er det lengste skjemaet (16 sider).

Bildeheftet ble vedlagt som supplement til 12- og 24-månedersskjemaene som hjelp til å bestemme mengder av en rekke matvarer og drikke. Til sammen er det bilder av 16 ulike matvarer/-retter. For hver av matvarene er det bilde av 4 ulike mengder. For grøt er det 6 ulike mengder. Det er også utviklet et bildeark med 2 bilder av hhv. 6 ulike mengder grøt og 4 ulike mengder morsmelkerstatninger som hjelp til å bestemme mengder ved utfylling av 6-månedersskjemaet.

I alle frekvensskjemaene er det i tillegg spørsmål om matvarer som unngås med tanke på å forebygge allergi og om spiseproblemer hos barnet.

Bakgrunnsdata om barnet og barnets foreldre samles inn via spørsmål i spørreskjemaene og ved innhenting av data fra SSBs registre: barnets kjønn, fødselstidspunkt i forhold til termin, tilsyn/pass på dagtid (kun 12- og 24-mnd-skjema), mors/barnets bosted (fylke, region, kommunetype), antall barn mor har født, mors alder, fødeland, utdanning, arbeidssituasjon, sivilstand og røykevaner (kun 6-mnd-skjema), fars utdanning (kun 12- og 24-mnd-skjema) og familiær belastning mht. allergi/astma.

Undersøkelsen krever oppdatering og supplering av data om matvarer, oppskrifter og næringsstoffer i matvaredatabasen ved Institutt for ernæringsforskning ved Universitetet i Oslo. Det er også gjennomført nye analyser av næringsstoffinnhold i utvalgte spedbarnsmatprodukter.

\section{VALIDERING AV METODEN}

I og med at det er første gang denne metoden er benyttet $\mathrm{i}$ en landsdekkende kostholdsundersøkelse blant sped- og småbarn, er det spesielt nødvendig å validere de nyutviklede frekvensskjemaene. En metodes validitet kan i prinsippet undersøkes på to måter. Resultatene kan sammenlignes med resultatene fra en annen 
kostholdsundersøkelsesmetode eller de kan sammenholdes med biologiske parametre (for eksempel i blod eller urin), såkalte biomarkører, på næringsstoffinntak. Metoden for kostholdsundersøkelse som anses å være best egnet som sammenlikningsgrunnlag (referansemetode) for et matvarefrekvensskjema, er en veieregistrering som pågår over tilstrekkelig lang tid (32-35). Veid registrering innebærer at forsøkspersonene veier og noterer alt som spises og drikkes etter hvert som konsumet finner sted. Ved validering mot biologiske parametre er det $\mathrm{i}$ dag kun et begrenset antall biomarkører som anses å være tilstrekkelig nøyaktige (reproduserbar og valid) til å validere kostholdsundersøkelsesmetoder (36). De to typene valideringsstudier har forskjellige begrensninger, og ideelt sett bør man derfor utføre begge typer.

\subsection{Validering av 12-månedersskjemaet}

Det gjennomføres en egen valideringsstudie av 12-månedersskjemaet høsten 1999 - våren 2000 i samarbeid mellom SEF, Institutt for ernæringsforskning og SNT. Veid registrering over 7 dager benyttes som referansemetode. De 7 dagene fordeles over en to-ukers periode; kostholdet til barnet registreres de første 4 dagene $i$ første uke og de siste 3 dagene i andre uke. Referansemetoden gjennomføres etter at foreldrene har fylt ut skjemaet, for å unngå læringseffekt fra registreringen ved utfylling av frekvensskjemaet. Det betyr at det ikke blir helt den samme tidsperiode som frekvensskjema og referansemetoden dekker. Statistisk sentralbyrå har trukket ut et utvalg på 350 barn født i Oslo av norske/andre skandinaviske mødre og som fyller 12 måneder høst 1999 - vår 2000. Resultater er ventet år 2000 .

\subsection{Validering av 24-månedersskjemaet}

Validering av 24-månedersskjemaet er gjennomført i Oslo våren 1999. Valideringsstudien er et samarbeid mellom prosjekt Spedkost/Småbarnskost og prosjekt Kosthold og ernæringsstatus blant norske sped- og småbarn ved Institutt for ernæringsforskning (9). Det var ca. 180 barn som deltok i valideringsstudien som omfattet å fylle ut 24-månedersskjemaet, ta blodprøve og gjennomføre 7-dagers kostregistrering (etterfølgende dager) med veiing. Blodprøven som tas gir mulighet til å måle biomarkører. Resultater er ventet i år 2000.

\section{OPPSUMMERING}

Den gode oppslutningen om undersøkelsen i første leveår gir en indikasjon på at metoden har fungert bra blant deltakerne mht. utfylling av spørreskjemaene og tid til å delta. I undersøkelsen blant 24-måneder gamle barn ble oppslutningen lavere. Dette kan indikere at foreldrene til 2-åringene opplever at de har knappere tid til å delta i denne type undersøkelser.

Validering av metoden vil si mer om hvor godt frekvensskjemaene fanger opp det barna spiser. Hovedresultater fra Spedkost og Småbarnskost er ventet i år 2000.

Vi takker Gry Hay, Torunn Ringheim, Dag S.Thelle og KarlOlaf Wathne for innspill ved utvikling av design og metode.

\section{REFERANSER}

1. Barker DJP, Winter PD, Osmond C, Margetts B, Simmonds SJ. Weight in infancy and death from ischaemic heart disease. Lancet 1989; ii: 577-80.

2. Hales CN, Barker DJP, Clark PMS, Clark PMS, Cox LJ, Fall C, Osmond C, Winter PD. Fetal and infant growth and impaired glucose tolerance at age 64. BMJ 1991; 303: 1019-22.

3. Kjærnes U, Botten G, Lande B, Nilsson D. Food intake and patterns of feeding of Norwegian infants. Eur $J$ Clin Nutr 1988; 42: 249-60.

4. Fagerli RAa. Jernstatus, kostutvikling og kosthold med særlig vekt på jerninntak blant friske ettåringer norske barn og innvandrerbarn i Drammensområdet. Cand.scient.oppgave. Oslo: Institutt for ernæringsforskning, Universitetet i Oslo, 1994.

5. Hay G. Kosthold og jernstatus hos norske toåringer - en undersøkelse av friske toåringer i Fredrikstad. Cand.scient.oppgave. Oslo: Institutt for ernæringsforskning, Universitetet i Oslo, 1995.

6. Fagerli RAa, Wandel M, Olsen PT, Ek J, Thorstensen K, Brekke O-L, Borch-Iohnsen B. Iron status and diet at two years of age: a longitudinal study of healthy Norwegian and immigrant children. Scand J Nutr 1996; 40: $58-63$.

7. Arsky GH. Kosthold, kostutvikling og jernstatus blant friske ettåringer - norske barn og innvandrerbarn i bydel Gamle Oslo. Cand.scient.oppgave. Oslo: Institutt for ernæringsforskning, Universitetet i Oslo, 1996.

8. Madar AA. Kosthold og jernstatus hos somaliske barn (2-4 år) i Osloregionen. Cand.scient.oppgave. Oslo: Institutt for ernæringsforskning, Universitetet i Oslo, 1997.

9. Hay, G. Institutt for ernæringsforskning, Universitetet i Oslo. Personlig meddelelse. 
10. Andersen LF, Nes M, Sandstad B, Bjørneboe G-E Aa, Drevon CA. Dietary intake in Norwegian adolescents. Eur J Clin Nutr 1995; 49: 555-64.

11. Andersen LF, Nes M, Bjørneboe G-EAa, Drevon CA. Food habits among 13-year-old Norwegian adolescents. Scand J Nutr 1997; 41: 150-4.

12. Johansson L, Solvoll K, Bjørneboe G-EAa, Drevon CA. Dietary habits among men and women. Scand J Nutr 1997; 41: 63-70.

13. Johansson L, Solvoll K. Norkost 1997. Landsomfattende kostholdsundersøkelse blant menn og kvinner i alderen 16-79 år. Rapport. Oslo: Statens råd for ernæring og fysisk aktivitet, 1999.

14. Statens ernæringsråds anbefalinger for spedbarnsernæring. Oslo: Statens ernæringsråd, 1993.

15. Liestøl K, Rosenberg M, Walløe L. Breast-feeding practice in Norway. Biosoc Sci 1988; 20: 45-58.

16. Solberg LK, Folkehelsa. Personlig meddelelse.

17. Nafstad P, Jaakkola JJK, Hagen JA, Stray Pedersen B, Qvigstad E, Botten G, Kongerud J. Weight gain during the first year of life in relation to maternal smoking and breast feeding in Norway. J Epidemiol Community Health 1997; 51: 261-5.

18. Nylander G, Matheson I. Amming. Effekt av røyking og utdanning. Tidsskr Nor Lageforen 1989; 109: 970-3.

19. Haug K, Irgens LM, Baste V, Markestad T, Skjærven R, Screuder P. Secular trends in breastfeeding and parental smoking. Acta Poediatr 1998; 87: 1023-7.

20. Michaelsen KF, Larsen PS, Thomsen BL, Samuelson G. The Copenhagen cohort study on infant nutrition and growth: duration of breast feeding and influencing factors. Acta Pcediatr 1994; 83: 565-71.

21. Lawson M. Recent trends in infant nutrition. Nutrition 1998; 14: 755-7.

22. Bærug A, Solberg LK, Kjærnes U. Amming i Finnmark - levekår og tilrettelegging. Fylkeslegens skriftserie nr. 2. Fylkeslegen i Finnmark, 1991.

23. Saarinen UM, Kajosaari M. Breastfeeding as prohylaxis against atopic disease: prospective follow-up study until 17 years. Lancet 1995; 346: 1065-9.

24. Vurdering av EU-direktivet for barnemat - ernæringsmessige konsekvenser. Notat. Oslo: Statens ernæringsråd, 1998.

25. Michaelsen KF. Nutrition and growth during infancy. Acta Pcediatr Suppl 1997; 420 : 19.

26. Lagerstrøm H, Seppänen R, Jokinen E, Niinikoski H, Rönnemaa T, Viikari J, Simell O. Influence of dietary fat on the nutrient intake and growth of children from 1 to $5 \mathrm{y}$ of age: the Special Turku Coronary Risk Factor Intervention Project. Am J Clin Nutr 1999; 69: 516-23.

27. Bærug A, Kjærnes U. Får norske spedbarn for lite jern i kosten? Tidsskr Nor Laegeforen 1991; 111: $1238-9$.

28. Norske næringsstoffanbefalinger 1997. Oslo: Statens ernæringsråd, 1997.

29. Undersøkelse om kosthold blant spedbarn. Notater nr. 8. Oslo: Statistisk sentralbyrå, 1999.

30. Undersøkelse om kosthold blant 12-måneder gamle spedbarn. Notater nr. 64. Oslo: Statistisk sentralbyrå, 1999.

31. Undersøkelse om kosthold blant 2-åringer. Notater nr. 65. Oslo: Statistisk sentralbyrå, 1999.

32. Nelson M, Bingham S. Assessment of food consumption and nutrient intake. I: Margetts BM, Nelson M, red. Design Concepts in Nutritional Epidemiology. Oxford: Oxford University Press, 1997: 123-70.

33. Willett WC, Reynolds RD, Cottrell-Hoehner S, Sampson L, Browne ML. Validation of a semi-quantitative food frequency questionnaire: Comparison with a 1-year diet record. J Am Diet Assoc 1987; 87: 43-7.

34. Block G, Woods M, Potosky A, Clifford C. Validation of a self-administered diet history questionnaire using multiple diet records. J Clin Epidemiol 1990; 43: 1327-35.

35. Hankin JH, Wilkens LR, Kolonel LN, Yoshizawa CN. Validation of a quantitative diet history method in Hawaii. Am J Epidemiol 1991; 133: 616-28.

36. Kohlmeier L. What you should know about your marker. I: Kok FJ, van't Veer, red. Proceedings of the $3^{\text {rd }}$ Meeting on Nutritional Epidemiology. Biomarkers of Dietary exposure. Rotterdam: Smith-Gordon, 1991. 